Volume 57

Issue 2 Winter 2008: Symposium - Challenges

to the Attorney-Client Relationship: Threats to

Article 13

Sound Advice?

\title{
Incentivizing Institutional Investors to Serve as Lead Plaintiffs in Securities Fraud Class Actions
}

Charles Silver

Sam Dinkin

Follow this and additional works at: https://via.library.depaul.edu/law-review

\section{Recommended Citation}

Charles Silver \& Sam Dinkin, Incentivizing Institutional Investors to Serve as Lead Plaintiffs in Securities Fraud Class Actions, 57 DePaul L. Rev. 471 (2008)

Available at: https://via.library.depaul.edu/law-review/vol57/iss2/13

This Article is brought to you for free and open access by the College of Law at Digital Commons@DePaul. It has been accepted for inclusion in DePaul Law Review by an authorized editor of Digital Commons@DePaul. For more information, please contact digitalservices@depaul.edu. 


\title{
INCENTIVIZING INSTITUTIONAL INVESTORS TO SERVE AS LEAD PLAINTIFFS IN SECURITIES FRAUD CLASS ACTIONS
}

\author{
Charles Silver* and Sam Dinkin**
}

\section{INTRODUCTION}

Congress's efforts to enlist institutional investors-pension funds, mutual funds, banks, and insurance companies-as lead plaintiffs in securities fraud lawsuits have partly succeeded. Since the enactment of the Private Securities Litigation Reform Act of 1995 (the PSLRA), ${ }^{1}$ pension funds for public sector employees and labor unions have often volunteered for the role. Private institutional investors, however, have been less active. ${ }^{2}$ Scholars have also questioned the motives of public and union funds, contending that activist ideologies and political contributions from attorneys have exerted inappropriate force. ${ }^{3}$

* Roy W. and Eugenia C. McDonald Endowed Chair in Civil Procedure and Co-Director, Center on Lawyers, Civil Justice \& the Media, School of Law, University of Texas at Austin. M.A., Political Science, University of Chicago, 1982; J.D., Yale Law School, 1987.

** Chief Economist, Optimal Auctions, Inc., Austin, Texas, Ph. D., Economics, University of Arizona, 1996. We are grateful for comments from Adam T. Savett.

1. Pub. L. No. 104-67, 109 Stat. 737 (1995) (codified as amended in scattered sections of 15 U.S.C.); 15 U.S.C. $\S 77 \mathrm{z}-1$ (2000); see also Securities Exchange Act of 1934, 15 U.S.C. $\S 78 \mathrm{u}-4$ (2000).

2. See James D. Cox \& Randall S. Thomas with Dana Kiku, Does the Plaintiff Matter? An Empirical Analysis of Lead Plaintiffs in Securities Class Actions, 106 Colum. L. Rev. 1587, 1609 (2006) (studying 260 post-PSLRA cases and finding no instance "where a bank, mutual fund, or insurance company ha[d] served as a lead plaintiff in a securities class action"). But see infra note 20 (listing cases where private institutions served as lead plaintiffs).

3. Commentators contend that political contributions are unethical, undermine the public's confidence in the legal profession, corrupt governments, encourage the selection of inferior counsel, lend an appearance of impropriety to fee setting, erect barriers that discourage new lawyers from entering the field, discourage monitoring by making lead plaintiffs dependent on class counsel, and sacrifice the interests of small investors. See, e.g., Brian C. Buescher, $A B A$ Model Rule 7.6: The ABA Pleases the SEC, But Does Not Solve Pay to Play, 14 Geo. J. LeGAL Errics 139 (2000); John C. Coffee, Jr., The Attorney as Gatekeeper: An Agenda for the SEC, 103 Colum. L. Rev. 1293 (2003); Samantha M. Cohen, Note, "Paying-to-Play" Is the New Rule of the Game: A Practical Implication of the Private Securities Litigation Reform Act of 1995, 1999 U. ILl. L. Rev. 1331; Malcolm A. Heinicke, Note, The ABA Should Not Delay on Pay-to-Play: Regulating the Political Contributions of Lawyers to Government Officials Who Award Legal Contracts, 49 Stan. L. Rev. 1523 (1997); Neil Weinberg \& Daniel Fisher, The Class Action Industrial Complex, Forbes, Sept. 20, 2004, at 150. Problems associated with partisan trustees of public sector investment funds are set out in David Hess, Protecting and Politicizing Public Pen- 
The passivity of private sector funds and the importance of special motivations for public and union funds have a common source: the microeconomic incentives created by the PSLRA, which saddles lead plaintiffs with exceptional costs and risks, but prohibits offsetting bonus payments. The PSLRA thus makes it economically irrational for class members to volunteer as lead plaintiffs, absent special motivations. Because private institutional investors care only about their bottom lines, they prefer to sit on the sidelines. Because trustees for public sector and union pension funds sometimes care about other things, such as improving corporate accountability and encouraging plaintiffs' attorneys to make political contributions, they volunteer more often.

To encourage private institutions to step forward, Congress should add selective incentives to the PSLRA. Selective incentives are emoluments that only lead plaintiffs can receive. This Article sets out three proposals Congress might use. One would give lead plaintiffs bonuses tied to the size of their holdings. Under this proposal, courts would give larger investors larger bonuses, creating stronger incentives for them to step forward. The second proposal would sell a sizeable fraction of the class-wide recovery-20\%-to the class member willing to pay the most for it and would require the lead plaintiff to defray a disproportionate share- $50 \%$ - of a class's attorneys' fee payment. This proposal would put a plaintiff with a sizeable stake at the head of every class, use competitive bidding to reduce the cost of the selective incentive, and encourage the winning bidder to set fees reasonably. The third proposal would also sell a fraction of the recovery to the class member willing to pay the most for it, but the fraction would be larger-30\%-and the lead plaintiff would pay the entire class's attorneys' fee from this portion. Compared with the first two proposals, this proposal would eliminate the burden on judges by transferring the responsibility for fees to lead plaintiffs and incentivizing them to pay efficient rates.

These proposals have one common feature: all would reward institutional investors for serving as lead plaintiffs by giving them disproportionately large shares of class action recoveries. The proposals would thereby create healthy competition for the lead plaintiff role. Unlike political contributions, which are only made to or on behalf of trustees of public sector and union pension funds, these proposals would motivate the managers of all types of funds. They would also

sion Fund Assets: Empirical Evidence on the Effects of Governance Structures and Practices, 39 U.C. Davis L. Rev. 187, 195-200 (2005). 
harmonize the interests of managers and beneficiaries by compensating investment funds rather than those who run them. Finally, all three proposals would reduce concerns about the impact political contributions may have on the quality of representation absent class members receive or the fees lead plaintiffs agree to pay. They would accomplish this by weakening the incentive to make political contributions and eliminating the need for private money to create special incentives for managers to volunteer their funds.

This Article proceeds as follows: Part II describes the legal structure embodied in the PSLRA. ${ }^{4}$ Part III shows how the PSLRA discourages institutional investors from serving as lead plaintiffs by enmeshing them in a collective action problem. ${ }^{5}$ Part IV describes the pay-to-play phenomenon and explains how it sometimes solves the collective action problem by giving public sector trustees selective incentives to offer their funds as lead plaintiffs. ${ }^{6}$ Part V sets out this Article's proposal and demonstrates its superiority to pay to play. ${ }^{7}$

\section{The Current Legal Environment}

Congress enacted the PSLRA in 1995, overriding President Clinton's veto. The statute implemented many reforms, some of which Congress designed to improve the conduct of private litigation. ${ }^{8}$ The PSLRA's lead plaintiff provision was one such reform. It created a presumption that the class member with the largest financial stake in the lawsuit was the "most adequate plaintiff" to occupy the lead plaintiff role. ${ }^{9}$

The lead plaintiff provision responded to the perception that securities class actions were "lawyer-driven" by seeking to foster greater

4. See infra notes 8-18 and accompanying text.

5. See infra notes 19-27 and accompanying text.

6. See infra notes $28-78$ and accompanying text.

7. See infra notes 79-118 and accompanying text.

8. Other provisions were designed to protect issuers from liability. Judging from the declining number of securities fraud lawsuits and falling recoveries per dollar of estimated loss, some have argued that these provisions have been effective. See Cox \& Thomas, supra note 2, at 1592 (noting that "[o]ne possible interpretation of [the statistically significant decline in the ratio of settlement amounts to estimated provable losses] is that Congress should repeal [the] PSLRA in its entirety if it wishes to help defrauded investors"). See also Cornerstone ResearCh, SECurities Class Action Case Filings, 2007 Mid-Year Assessment, http://securities.stanford. edu/clearinghouse_research/2007_YIR/20070710-01.pdf (chronicling the decline in securities class action filings). This interpretation is disputed, however. See Press Release, Stanford Law School and Cornerstone Research Release Mid-Year Securities Fraud Class Action Filings Report (July 10, 2007), available at http://home.businesswire.com/portal/site/google/index.jsp?ndm ViewId=news_view\&newsId=20070710005784\&newsLang=en (identifying lower fraud rates and a strong stock market as likely causes of declining securities fraud filings).

9. See 15 U.S.C. $\$ 77 \mathrm{z}-1$ (2000). 
client control. ${ }^{10}$ Several factors contributed to the attorneys' primacy under the prior regime. Chief among them was the race to the courthouse, the winner of which would typically gain appointment as class counsel and receive most of the fees. Given this race, lawyers did not wait for clients to find them when likely frauds appeared. They had to submit complaints on the heels of sharp declines in stock prices and adverse news reports. To do so, lawyers needed cooperative clients who would lend their names to lawsuits immediately.

Class action lawyers may have also preferred unsophisticated named plaintiffs with small holdings for other reasons. ${ }^{11}$ Sophisticated clients with sizeable stakes might have been less malleable and more independent. They may have cared more about the quality of the legal services they received, monitored lawyers more closely, second-guessed lawyers' recommendations, sought outside opinions, criticized poor performance, and even discharged attorneys who performed poorly. Larger clients also might have been more concerned about lawyers' fees. Lesser attorneys would have disfavored such clients. Even superior attorneys might have wondered why they should tie themselves to such clients unnecessarily.

By enacting the PSLRA and, in particular, its lead plaintiff provision, Congress sought to replace figurehead named plaintiffs with institutional investors. The idea, explored in a famous article by Professors Weiss and Beckerman, was that investors with large holdings and, consequently, large financial interests in the outcome of class litigation would select good lawyers, bargain hard over fees, and actively monitor the conduct of litigation, producing spillover benefits for all defrauded investors. ${ }^{12}$ "The Congress clearly envisioned that various financial institutions-pension funds, insurance companies, and mutual funds-were the most likely types of investors who could combine a large financial stake in the suit's outcome with the sophistication to guide the suit to an appropriate result."13

10. Geoffrey P. Miller, Payment of Expenses in Securities Class Actions: Ethical Dilemmas, Class Counsel, and Congressional Intent, 22 REv. Litig. 557, 593 (2003).

11. The government has accused lawyers at Milberg Weiss, once the country's leading securities class action firm for plaintiffs, of paying illegal kickbacks to individual clients, and the firm itself has been indicted. Mike McIntire, Accused Law Firm Continues Giving to Democrats, N.Y. Times, Oct. 18, 2007, at A1. Several lawyers and clients have entered guilty pleas. Associated Press, Another Guilty Plea in Milberg Weiss Case, N.Y. Times, Oct. 19, 2007. From a strictly economic perspective, the alleged payments provided supplemental incentives that ensured the clients' availability and cooperation.

12. Elliott J. Weiss \& John S. Beckerman, Let the Money Do the Monitoring: How Institutional Investors Can Reduce Agency Costs in Securities Class Actions, 104 Y ALE L.J. 2053, 2112 (1995).

13. Cox \& Thomas, supra note 2 , at $1588-89$. 
To increase the likelihood that institutional investors would appear in securities class actions, the PSLRA added a notice procedure to the race to the courthouse. After filing a complaint, a would-be lead plaintiff must publish a notice in a "widely circulated national business-oriented publication or wire service," 14 informing other class members of the existence of the action and the possibility of intervening. Other investors can then apply for the lead plaintiff role. When the application deadline passes, the trial judge "appoints as lead plaintiff the member or members of the purported plaintiff class that the court determines to be 'most capable of adequately representing the interests of class members." "15 The investor or group of investors with the "largest financial interest in the relief sought" is statutorily presumed to be the most adequate plaintiff and is normally appointed. ${ }^{16}$

The lead plaintiff role carries certain responsibilities. For example, the lead plaintiff must demonstrate familiarity with the litigation and select and retain class counsel. ${ }^{17}$ Under recent precedents, the latter responsibility includes setting class counsel's compensation terms. ${ }^{18}$ Finally, a lead plaintiff must agree to accept no more than a pro rata share of damages, plus expense reimbursements. This seemingly innocuous requirement has undermined the PSLRA by discouraging institutional investors from taking the lead in securities fraud cases.

\section{Participation Rates}

The PSLRA only partly succeeded in encouraging institutional investors to appear as lead plaintiffs. ${ }^{19}$ Today, as before, individual investors control many securities fraud cases. Among institutional investors, retirement funds for public and union employees actively offer themselves as lead plaintiffs. Private institutional investors appear less frequently. ${ }^{20}$ Taking participation by private institutional in-

14. 15 U.S.C. $\& 77 \mathrm{z}-1$ (a)(3)(A)(i) (2000).

15. Miller, supra note 10 , at 594-95 (quoting 15 U.S.C. $\$ \S \quad 77 z-1(a)(3)(B)(i)$, $78 \mathrm{u}-4(\mathrm{a})(3)(\mathrm{B})(\mathrm{i})(2000))$.

16. 15 U.S.C. $\$ 77 \mathrm{z}-1(\mathrm{a})(3)$ (B)(iii) (2000).

17. See In re Microstrategy, Inc. Sec. Litig., 150 F. Supp. $2 d 896$ (E.D. Va. 2001).

18. See, e.g., In re Cendant Corp. Sec. Litig., 404 F.3d 173 (3d Cir. 2005).

19. For a review of institutional investors' participation as lead plaintiffs, see Stephen J. Choi \& Robert B. Thompson, Securities Litigation and Its Lawyers: Changes During the First Decade After the PSLRA, 106 Colum. L. Rev. 1489, 1503-07 (2006). See also Stephen J. Choi et al., Do Institutions Matter? The Impact of the Lead Plaintiff Provision of the Private Securities Litigation Reform Act, 83 WASH. U. L.Q. 869 (2005) (reporting that institutional investors rarely served as lead plaintiffs in the years immediately following the PSLRA's enactment).

20. Adam T. Savett, who maintains the Securities Litigation Watch blog for Institutional Shareholder Services, contends that private institutional investors serve as lead plaintiffs more often than academics perceive. See Risk Metrics Group, Sec. Litig. Watch, http://slw.issproxy. 
vestors as the measure of success, the PSLRA has not fulfilled its sponsors' expectations. ${ }^{21}$

Various sources have examined the participation levels of private institutional investors. ${ }^{22}$ Some studies, the most notable being PricewaterhouseCoopers's (PWC) annual reports on securities lawsuits, found positive levels of participation. ${ }^{23}$ Unfortunately, the PWC reports are unclear. They neither list lead plaintiffs nor explain how they categorize them. The 2003 PWC report also seems implausible. It implies that private sector funds served as lead plaintiffs in 53 of the 218 new securities class actions filed in 2002.24 This level of participation, which would put private institutions almost on par with public sector and union pension funds, would imply that informed observers of securities class actions missed a hugely important development in the field.

The 2004 PWC report also undercuts the report issued the prior year. It contains the figures reproduced below, according to which private institutions led only $13 \%$ of the class actions filed in 2003 about 28 cases. ${ }^{25}$ Even this number seems high in light of commentators' remarks. The 2004 report also indicates that private institutions again led $13 \%$ of newly filed securities class actions in 2004, thus finding no growth from one year to the next. ${ }^{26}$ Over the same period, the frequency with which union and public sector funds appeared as lead

com/lead_plaintiff_lead_counsel/; and http://slw.issproxy.com/2007/03/the_quixotic_quest_continues.html (last visited Oct. 11, 2007). He has posted fifteen cases on this subject. Adam T. Savett Blog, Lies, Damn Lies, \& Forward Looking Statements, http://liesdamnlies.blogspot.com/ 2006/03/mutual-funds-as-lead-plaintiffs.html; http://liesdamnlies.blogspot.com/2006/03/mutualfunds-as-lead-plaintiffs-part.html; http://liesdamnlies.blogspot.com/2006/03/mutual-funds-aslead-plaintiffs-part_31.html (last visited Oct. 11, 2007). We are grateful to him for bringing these cases to our attention. But cf. Choi \& Thompson, supra note 19, at 1504 ("There has been a substantial increase in participation of public pension firms .... At the same time, there has not been substantial involvement by private institutional investors, such as mutual funds, banks, and insurance companies.").

21. See John C. Coffee, Jr., Litigation Governance: A Gentle Critique of the Third Circuit Task Force Report, 74 Temp. L. Rev. 805, 806 n.7 (2001) (observing that few institutional investors have served as lead plaintiffs).

22. For a discussion, see Michael A. Perino, Institutional Activism Through Litigation: An Empirical Analysis of Public Pension Fund Participation in Securities Class Actions (St. John's Univ. Legal Studies Research Paper Series, Paper No. 06-0055, Oct. 2006).

23. See infra notes $24-25$ and accompanying text.

24. PricewaterhouseCoopers LLP, 2003 Securities Litigation Study (2004). The 2003 PWC Report states that "[i]n 2002 institutional investors and public investment or pension funds comprised 51 percent of the lead plaintiffs for all [218] cases filed." Id. at 6 . This totals 111 cases. Then, the following appears: "by 2002 , union/public pension funds were lead plaintiffs in 58 out of the 218 cases filed ( 27 percent) ...." Id. By simple subtraction, it follows that private sector funds must have taken the lead fifty-three times.

25. PricewaterhouseCoopers LlP, 2004 Securities Litigation Study 15 (2005).

26. Id. 
plaintiffs rose from $28 \%$ to $34 \%, 27$ supporting the claim that these funds have become more active and have displaced individual investors. Individuals led almost half of the cases filed in 2003, but only $35 \%$ of those filed in 2004 .

Lead plaintiff in securities class action cases filed in $2003^{\prime}$

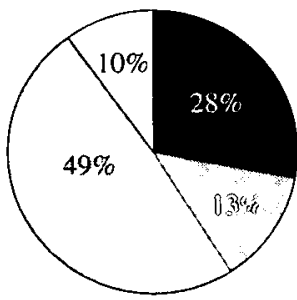

Union \& Public pension fund

Institutional investor ${ }^{2}$
Lead plaintiff in securities class action cases filed in $2004^{1.4}$

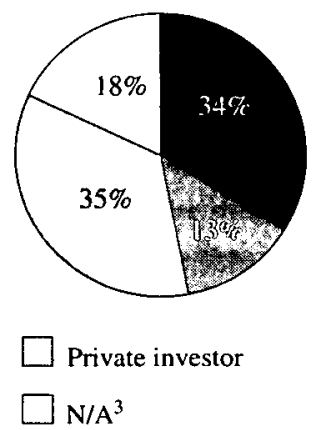

'Excludes "Analyst," and "Fund" cases

${ }^{2}$ Excludes public pension funds.

${ }^{3}$ Includes cases that have been consolidated or dismissed before a lead plaintiff was determined, and others where lead plaintiff could not be determined.

${ }^{4} 2004$ data is not fully available to date; therefore full-year projections are based on mid-year results.

Source: PriceWaterCoopers LlP, 2004 Securities Litigation Study 15 (2005)

\section{InVESTORS' InCENTIVES}

The preceding discussion showed that different types of investors occupy the lead plaintiff position at different rates. Individuals participate as often as public and union pension funds, but, if the existing trends continue, will soon be overtaken by them. Private institutional investors lead class actions less often and seem unlikely to become substantially more active.

To explain these findings, one must understand that all named plaintiffs bear costs. For example, they hire counsel, monitor counsel, and respond to discovery requests. To make these costs worthwhile, named plaintiffs must expect to receive offsetting benefits. Economically rational persons sue only when they expect litigation to be profitable.

In class actions, the possibility of free-riding discourages potential lead plaintiffs from stepping forward. In an ordinary lawsuit, an in- 
jured person can obtain a benefit only by becoming a cost-bearing party. In a class action, a victim can share in the recovery while doing almost nothing. For example, in a securities class action, an unnamed investor can simply wait for a settlement and file a claim. Most of the money paid out in class action settlements goes to investors who do just that.

The ability to share in a recovery without helping to produce it creates a classic collective action problem. Rather than bear the costs and risks the lead plaintiff role entails, the rational strategy is to wait for someone else with different motivations to sue and subsequently enjoy the benefit if and when it is produced. This free-riding is the dominant strategy as long as one can be reasonably confident that someone else will sue. In securities class actions, this is extremely likely. Plaintiffs' attorneys watch the stock market vigilantly, hoping to spot lucrative litigation opportunities.

Even if an institutional investor were confident that no one else would step forward, an incentive to file a class action would not necessarily arise. Individual lawsuits are cheaper than class actions, which entail expensive procedures like certification hearings, notice, interlocutory appellate review, and judicial approval of settlements and fees. Class actions can also water down institutional investors' claims by mixing them with individual investors' weaker claims. For this reason, large investors sometimes opt out of class actions and sue on their own. ${ }^{28}$ Given the alternatives, an institutional investor's equilibrium strategy is to free-ride on a class action led by another investor or to file a conventional lawsuit.

This brief description of the incentives that prevail in class actions is incomplete. Most obviously, it fails to explain why plaintiffs file between one hundred and two hundred securities class actions per year. ${ }^{29}$ For individual investors, a combination of entrepreneurial lawyering and small selective incentives provide the spark. Using contingent fee agreements, entrepreneurial lawyers transfer to themselves the largest possible share of the costs associated with the lead plaintiff

28. John C. Coffee, Jr., Nobody Asked Me, But . . , N.Y. L.J., Jan. 18, 2007, at 1 ("Increasingly, institutional investors have been opting out of federal class actions to sue individually or in small groups in state court."); Cox \& Thomas, supra note 2, at 1604 ("Institutional investors with large potential claims have sometimes found it more advantageous to act for themselves rather than on behalf of all other investors."); Jay W. Eisenhofer, Institutional Investors as Trend-Setters in Post-PSLRa Securities Litigation, in Class Action Litigation 2006: Prosecution and Defense Strategies 579, 590-93 (Practising L. Inst. 2006) (discussing the pros and cons of opting out of class actions as a strategy for institutional investors).

29. See Stanford Law Sch., Stanford Securities Class Action Clearinghouse, Class Action Filings Index, http://securities.stanford.edu/litigation_activity.html (last visited Oct. 11, 2007). 
role. They bear all costs associated with attorney time, discovery, and expert witnesses, in exchange for a share-historically $25 \%$ to $35 \%$ of any common fund recovered by the class. Bonus payments negotiated in settlements then cover lead plaintiffs' remaining costs, such as time spent attending depositions, responding to interrogatories, and reviewing pleadings. These bonuses are small in absolute dollar terms and as fractions of classes' recoveries. Nevertheless, the bonuses provide significant incentives, because they are generous when compared with individual plaintiffs' actual costs.

Contingent fees and settlement bonuses produce a combination of weak incentives for individual lead plaintiffs and strong incentives for their attorneys, who usually hold the largest stakes in the class-wide recovery. Predictably, these incentives lead to lawyer-driven litigation. As the largest stakeholder, the class action attorney identifies the opportunity for litigation, confects the lawsuit, races to the courthouse, and takes the lead in other ways. The lead plaintiff, with a much smaller stake in the outcome, goes along for the ride, a contented passenger who does not wish to drive.

The PSLRA reflected Congress's opposition to lawyer-driven litigation. Seeking to replace passive named plaintiffs with active ones, Congress enacted the lead plaintiff provision, which replaced the competition over speed with a competition over size. The race that formerly went to the first lawyer to reach the courthouse now goes to the lawyer able to secure the blessing of the client with the biggest loss. The incentive for lawyers to recruit institutional investors is obvious: by lining up the institution with the largest financial stake, a lawyer gained control of the case and the opportunity to earn a fee. The PSLRA's catch phrase might be "size matters."

The incentive for institutional investors to respond favorably to plaintiffs' attorneys' overtures was not as obvious, however. ${ }^{30}$ First, many institutions depend on public companies for business: "[b]anks, mutual funds, and insurance companies-three of the five largest classes of financial institutions-are each vendors of financial services and products. Their customers include the corporations and accounting firms who are the grist of securities class actions." 31 By becoming lead plaintiffs in securities class actions, private institutions could jeopardize their relationships with important customers. Second, institutional investors have historically been reluctant participants in securities

30. See Choi \& Thompson, supra note 19 , at 1504-05 (describing the free-rider problem and institutional investors' other disincentives to participation).

31. Cox \& Thomas, supra note 2, at 1609. 
fraud lawsuits. Most lack litigation departments; ${ }^{32}$ many even fail to claim payments when class actions settle. ${ }^{33}$

Finally, institutional investors have never been on close terms with class action attorneys. Returns from litigation ordinarily have little impact on their bottom lines, which depend overwhelmingly on the performance of securities and, therefore, on access to corporate boardrooms and analysts. By suing for fraud, institutional investors risk alienating those constituencies:

Consorting with "class action lawyers" does not win one friends in the executive suites of America or at the club. Furthermore, there is only the thinnest social divide between executives of banks, insurance companies, and mutual funds and executives of industrial firms. These are groups of individuals who understand one another and who are aware of the price to be incurred by failing to honor that understanding. ${ }^{34}$

The divide between friends and enemies forces institutional investors to pick sides. Naturally, they align themselves with the business world, of which they are a part.

The bonuses that entice individual investors to volunteer as lead plaintiffs are far too small to attract institutions. To convince institutional investors to enter the game, Congress needed to create selective incentives. Instead, Congress did the opposite. ${ }^{35}$ It entrenched the rationality of free-riding by limiting a lead plaintiff's recovery to the same amount per share as other class members. ${ }^{36}$ It also made no provision for bonus payments, entitling class representatives to recover only their actual costs and requiring them to forswear other payments. These arrangements made it unprofitable for institutions to participate. As Cox and Thomas wrote, "the costs of initiating and

32. Perino, supra note 22, at 7 ("Many institutions have relatively small legal staffs that would have difficulty conducting in-depth investigations of the potential merits of cases in which they were considering seeking lead plaintiff status.").

33. James D. Cox \& Randall S. Thomas, Leaving Money on the Table: Do Institutional Investors Fail to File Claims in Securities Class Actions?, 80 WAsH. U. L.Q. 855, 879 (2002). This omission has spawned shareholder litigation. Institutional Shareholder Servs., The Fiduciary Duty to File Claims In Securities Class Action Settlements (Jan. 2005) (reporting that shareholder class actions were brought against forty mutual fund managers, alleging that the managers breached their fiduciary duties by failing to collect as much as $\$ 2$ billion in settlement payouts).

34. Cox \& Thomas, supra note 2, at 1609-10.

35. Congress often embraces the Pollyannaish belief, popularized in the movie Field of Dreams, that "if you build it, they will come." See David A. Hyman \& Charles Silver, The Poor State of Health Care Quality in the U.S.: Is Malpractice Liability Part of the Problem or Part of the Solution?, 90 Cornell L. Rev. 893, 988 (2005) (pointing out Congress's failure to build incentives to report errors into the Patient Safety and Quality Improvement Act of 2004 and criticizing Congress's assumption that medical providers will file error reports voluntarily because they will have "little to lose").

36. 15 U.S.C. $\$ \S 77 z-1(a)(2)(A), 78 u-4(a)(2)(A)(2000)$. 
sponsoring action [against issuers] are borne by the activists, while any benefits fall proportionately among all members of the group." 37

Getting institutions to step from the sidelines onto the playing field requires larger bonuses than individual investors historically received. It costs individual investors little to serve as lead plaintiffs. They often know nothing about the alleged fraud and contribute few other services. ${ }^{38}$ They also have low opportunity costs. Consequently, small bonus payments are sufficient to win their consent. Institutional investors have more knowledge, higher out-of-pocket costs, and higher opportunity costs. Assuming a rate of $\$ 100$ per hour for personnel time, Cox and Thomas estimated that "the cost of a reasonable case management effort by an institutional investor lead plaintiff in an 'average' case would total between $\$ 25,000$ and $\$ 100,000$." 39

The opportunity cost might be considerably greater. Suppose a lead plaintiff could spend two thousand hours managing a $\$ 100$ million hedge fund ${ }^{40}$ and earn the standard hedge fund management fee- $-2 \%$ of assets ( $\$ 2$ million) plus $20 \%$ of returns of $10 \%$ per annum ( $\$ 2$ million), for a total of $\$ 4$ million. ${ }^{41}$ At this rate of return, the opportunity cost of spending 250 to 1,000 hours on a securities lawsuit would be between $\$ 500,000$ and $\$ 2$ million. Dollar-for-dollar reimbursement provides no incentive to bear these costs. This is especially true in light of the risk of losing the opportunity cost of diverting employees from more profitable business activities to monitoring litigation, "the potential for disclosure of proprietary nonpublic information," the danger of losing access to inside information going forward, and the possibility of being sued by disgruntled plaintiffs. ${ }^{42}$

Some could argue that institutional investors can increase classwide recoveries and cut legal fees by serving as lead plaintiffs, thereby boosting their own pro rata shares. Even if this were true-and it may

37. Cox \& Thomas, supra note 2 , at 1606.

38. Id. at 1608 (comparing the effort levels of individual investors and institutions and concluding that lead plaintiffs who are individuals are not likely to engage in the extensive involvement characteristic of institutions).

39. Id.

40. "The median hedge fund size in this year's survey was approximately $\$ 124$ million." Press Release, Hennessee Releases 9th Annual Hedge Fund Manage Survey (Apr. 3, 2003), available at http://www.hennesseegroup.com/releases/release20030403.html.

41. "Hedge funds almost always have a fee structure that includes both a fixed fee and a management fee. The fixed fee usually ranges between 1 and $2 \%$ of assets under management and the management fee ranges between 20 and $25 \%$ of upside performance." Neil A. Chriss, Introduction to Hedge Funds, Lecture at N.Y.U., Dec. 1998, available at http://www.math.nyu. edu/faculty/chriss/neil/lecture12/hedgefunds.htm (last visited Oct. 11, 2007).

42. Cox \& Thomas, supra note 2, at 1602; accord Weiss \& Beckerman, supra note 12, at 2103. 
be ${ }^{43}$-it would not encourage institutional investors to jump into the fray. First, recoveries for all investors would grow in the manner described if any institution were to step forward. Consequently, the beneficial impact of institutional participation merely converts an enormous collective action problem among all investors into a smaller collective action problem among all institutions holding shares, with each institutional investor wanting another to take the lead. ${ }^{44}$ Second, because institutional investors can file conventional lawsuits at less cost than class actions and with greater control, the possibility of increasing the net recovery gives an institutional investor no reason to represent a class. Individual lawsuits, however, do not vindicate other investors' claims. ${ }^{45}$

In theory, public sector and union pension funds might behave like other institutional investors. They might refrain from taking the helm in securities class actions for the same reasons as other institutions. Yet these funds have often stepped forward, and their activism appears to be increasing. Three forces appear to motivate them: weaker ties to corporate boards, ideology, and political contributions.

\section{A. Corporate Ties and Ideology}

Relationships between public sector investment funds and public companies are less cozy than those between private institutions and those companies, partly because public sector funds do not depend on public companies for business. They do not sell financial or other consulting services that private institutions often find lucrative. Separation also occurs, because most trustees of public sector funds are elected officials or political appointees whose motives are mixed. ${ }^{46}$ As fiduciaries, they must protect beneficiaries. As partisans, they must cultivate political support. To some observers, the latter motivation seems stronger: "researchers argue that politically-appointed trustees

43. Cox \& Thomas, supra note 2 , at 1631.

44. Jill Fisch described the problem as follows:

"[I]nstitutions, particularly those concerned about minimizing administrative costs generally, are rationally apt to prefer that another investor take the initiative to become involved." In fact, one attorney who represents institutional investors in securities fraud class actions told us that the first question his clients ask before considering undertaking a lead plaintiff position is whether any other institution is willing to do it.

Id. at 1606 (quoting Jill E. Fisch, Class Action Reform: Lessons from Securities Litigation, 39 Ariz. L. Rev. 533, 542 (1997)).

45. Id. at $1603 \mathrm{n} .62$ (reporting that institutions sometimes opt out of class actions and sue on their own).

46. See Hess, supra note 3, at 195-200 (reporting that, of public sector funds in the PENDAT database, $36 \%$ of the members of the average board were elected by beneficiaries, and the remainder were elected officials or political appointees). 
do not make decisions based on the interests of pension beneficiaries, but principally to improve their own political situations." 47 If this is correct, partisan trustees should enlist their funds as lead plaintiffs when they can "improve their own political situations" by doing so. Presumably, the most beneficial cases are high-profile ones, like Enron and WorldCom, which can attract significant media attention and generate substantial settlements. The findings generated by Cox and Thomas suggest that public trustees focus on significant and serious frauds. ${ }^{48}$ Using multiple regression analysis, they determined that public sector funds were more likely to become lead plaintiffs in cases involving "large capitalization firms, with bigger estimated losses, and when the SEC ha[d] filed a parallel action." 49

Ideology may also motivate public pension funds' trustees. They may want to "fix the system" by "improv[ing] the effectiveness of class action litigation," "strengthen[ing] the financial reporting process," and obtaining "recoveries from individual corporate officers and directors" rather than just their insurers. ${ }^{50}$ The strategy of focusing on high-profile cases is consistent with these objectives.

Labor union pension funds may also actively seek to become lead plaintiffs for many of the same reasons. Labor leaders who manage pension funds "often wear two hats, protecting their interests as shareholders but also furthering their interests as workers." 51 These interests do not always conflict. ${ }^{52}$ As shareholders, union members benefit from measures that increase the value of their firms. They may also benefit from measures, such as wage increases, that transfer wealth from shareholders to workers-although this motivation seems unlikely to figure strongly in their decisions to become lead plaintiffs. Securities lawsuits have little potential to help workers as employees, other than by improving corporate governance.

\section{B. Political Contributions}

Contributions to public sector fund trustees and union-related political action committees came into vogue after Congress enacted the PSLRA. In a further demonstration of the law of unintended consequences, the Act replaced the much maligned race to the courthouse

47. Id. at 196 .

48. Cox \& Thomas, supra note 2 , at 1630.

49. $I d$.

50. Id. at 1605 .

51. Id. at 1610 n. 93 .

52. See Stewart J. Schwab \& Randall S. Thomas, Realigning Corporate Governance: Shareholder Activism by Labor Unions, 96 Mich. L. REv. 1018, 1074-84 (1998). 
with an equally reviled competition to curry the favor of pension fund trustees. Political contributions are the currency of the new competition. Although the volume and frequency of class action lawyers' political contributions are unknown, anecdotal reports abound. A USA Today article reported the following examples, which the newspaper unearthed by studying campaign-finance records and pleadings: ${ }^{53}$

- Lawyers who contributed \$156,000 to Mayor Edward Rendell's campaigns represented the City of Philadephia's Board of Pensions and Retirement in a class-action case against Ikon Office Solutions and shared more than $\$ 32$ million in legal fees. ${ }^{54}$ The same lawyers also contributed to Pennsylvania Treasurer Catherine Baker Knoll, who hired them to represent the state's pension funds.

- After the PSLRA took effect, law firms specializing in securities class-action cases started contributing to Ken Duncan, Louisiana's state treasurer and overseer of the state's retirement funds. They also gave to the campaign of John Kennedy, who unseated Duncan in 1999. After Duncan lost, a securities firm hired him to help guide its quest to represent other public pension funds.

- Securities firms numbered among the top contributors to New York City Comptroller Alan Hevesi, a noted activist who helped hire these firms to represent the municipal pension system. ${ }^{55}$

These examples are the tip of the iceberg. Judging by the number of stories and commentaries, as well as the strong push for regulation, political contributions are widespread. 56

Class action lawyers also use lobbyists to advance "their efforts to obtain the lead counsel position." 57 To confirm this, Cox and Thomas visited "state-posted electronic information about lobbyists." 58 Their

53. Kevin McCoy, Campaign Contributions or Conflicts of Interest?, USA TodAy, Sept. 11, 2001, at B1.

54. Id.; see also In re IKON Office Solutions, Inc. Sec. Litig., 194 F.R.D. 166 (E.D. Pa. 2000) (approving the proposed settlement).

55. McCoy, supra note 53; see also Karen Donovan, Legal Reform Turns a Steward Into an Activist, N.Y. Times, Apr. 16, 2005, at C1. Hevesi resigned under a cloud after being found to have used state employees as chauffeurs and aides to his wife. Michael Cooper, Hevesi to Resign and Avoid Jail, Official Reports, N.Y. TIMEs, Dec. 22, 2006, at A1.

56. For examples of contributions, see supra note 3 and accompanying text. See also In re Cendant Corp. Litig., 182 F.R.D. 144 (D.N.J. 1998) (rival for the position of lead plaintiff argued that the New York State Pension Fund and the New York City Pension Fund should be disqualified on the grounds that their overseers received political contributions from the lawyers they retained); Daniel Fisher, Bedfellows, Forbes, Feb. 13, 2006, at 102 (reporting on contributions to labor unions' political action committees by lawyers who represented the unions' pension funds in securities class actions); Brian Grow, The Kings Of Class Actions, Business Week, May 16 , 2005 , at 50 (reporting on the success of class action lawyers known to have made political contributions); Diana B. Henriques, Conflict Over Conflicts: Class-Action Lawyers Defend Their Political Contributions, N.Y. Times, July 30, 1998, at C1.

57. Cox \& Thomas, supra note 2 , at 1613.

58. Id. at 1591 . 
search revealed "evidence that plaintiffs' law firms have hired lobbyists in several states."59 Because publicly available information on lobbyist engagements is limited, law firms probably use them more often than state websites reveal. Cox and Thomas "also learned from pension fund officials that these lobbyists have attempted to persuade them to act as lead plaintiffs." 60

The incentive to influence public officials arises in securities fraud lawsuits, because the managers of public sector and union pension funds decide whether these funds will serve as lead plaintiffs and which lawyers they will hire. Under the PSLRA, the class member with the largest stake is presumptively the most adequate lead plaintiff and will receive control of the case, including the right to appoint class counsel and negotiate attorneys' fees. ${ }^{61}$ Public sector funds, which collectively own over $10 \%$ of the domestic equities market, often qualify for this role. ${ }^{62}$ Consequently, lawyers intent on becoming class counsel find it advantageous to build relationships with public sector fund trustees and to support activist trustees with political contributions. By contributing, lawyers gain "access to politicians" and "a chance to transact in the political marketplace." 63

Commentators uniformly find political contributions objectionable. Professor Coffee urged Governor Elliot Spitzer to "address[ ] the "pay for play' practices associated with New York State's pension funds" as part of an overall effort to clean up politics. ${ }^{64}$ Cox and Thomas complained that "the PSLRA was not enacted to create further angst over how political fundraising might compromise the judgment and trust of elected officials." 65 To date, however, there is little concrete evidence of harm. Political contributions may cause lead plaintiffs to select less qualified attorneys, approve cheap settlements, or offer inflated fees, ${ }^{66}$ but examples are hard to spot. ${ }^{67}$

\section{Id.}

60. Id.

61. 15 U.S.C. $\$ 77 \mathrm{z}-1(\mathrm{a})(3)(\mathrm{B})(\mathrm{v})(2000)$ ("The most adequate lead plaintiff shall, subject to the approval of the court, select and retain counsel to represent the class.").

62. Hess, supra note 3, at 195-200.

63. Fred S. McChesney, "Pay to Play" Politics Examined, with Lessons for Campaign-Finance Reform, 6 The INDEPENDENT Rev. 345, 346 (2002).

64. See John C. Coffee, Jr., "When Smoke Gets In Your Eyes": Myth and Reality About the Synthesis of Private Counsel and Public Client, 51 DePaul L. Rev. 241, 249 (2001); Coffee, Jr., supra note 28.

65. See Cox \& Thomas, supra note 2, at 1617.

66. See, e.g., Coffee, Jr., supra note 28 (arguing that the clearest problem caused by political contributions "is that a conflicted client is less likely to object to a cheap settlement favored by the plaintiff's law firm or to an inflated plaintiff's fee award").

67. See Jill E. Fisch, Lawyers on the Auction Block: Evaluating the Selection of Class Counsel by Auction, 102 Colum. L. Rev. 650, 703-10 (2002) (finding that institutional investors hired 
Assuming those who condemn political contributions are right, the surest way to eliminate these payments would be to privatize the operation of public employees' pension funds. Private companies often manage public employees' money. Public employees might even benefit from privatization, which can improve returns and harmonize the interests of managers and beneficiaries. ${ }^{68}$ Such benefits would likely come at the cost of higher private sector pension fund salaries and the accompanying envy, however. Privatization would not eliminate class action lawyers' incentives to seek business, but would convert the activity from raising fears of public corruption to private sector solicitation.

Critics of pay to play in securities class actions have not recommended privatization. Most have called for regulations limiting or prohibiting political contributions. Both Professor Coffee and Professors Cox and Thomas would bar public officials from employing contractors from whom they receive political contributions, ${ }^{69}$ a ban already in place in some states. ${ }^{70}$ In support of this suggestion, these commentators point to a regulation adopted in 1994 by the Municipal Securities Rulemaking Board (MSRB) "to govern relationships between broker-dealers who underwrite municipal securities and the elected officials who select the underwriters."71 Others share the desire to extend the MSRB approach to class-action attorneys. ${ }^{72}$

Unfortunately, the MSRB has had difficulty preventing dealers and other municipal finance professionals (MFPs) from using political contributions to influence assignments. After the MSRB's basic prohibition appeared in 1994, MFPs started using consultants as conduits for contributions, causing the MSRB to adopt a second prohibition in

high-quality law firms, established long-term relationships with them, reduced fees, and used fee arrangements that reduced agency costs).

68. Hess, supra note 3, at 195-200.

69. See Coffee, Jr., Nobody Asked Me, supra note 28; Coffee, Jr., When Smoke Gets in Your Eyes, supra note 64; Cox \& Thomas, supra note 2, at 1614. Cox and Thomas also recommended that lawyers disclose political contributions to judges and institutions to develop internal procedures to weaken contributions' impact. Id. at 1638-39.

70. McCoy, supra note 53 (reporting that Connecticut and Vermont have such prohibitions). See also Pauline A. Schneider, Attempts to Limit Political Contributions by Municipal Finance Professionals and Lawyers, 1508 PLI/Corp 345, 355 (Sept. 2005) (reporting that New Jersey, Connecticut, Wisconsin, Tennessee, and Illinois "prohibit contracts for periods of time with companies or individuals that have made political contributions to elected officials who are in a position to influence the award of contracts").

71. Cox \& Thomas, supra note 2, at 1614-15.

72. Interim Report of The Committee on Capital Markets Regulation (Dec. 5, 2006), available at http://www.capmktsreg.org/pdfs/11.30Committee_Interim_ReportREV2.pdf. 
1996. ${ }^{73}$ Money also flowed via bond attorneys, according to New York Senator Franz S. Leichter, who found that New York's fourteen largest bond counsel firms gave more than $\$ 530,000$ to state politicians from 1994 to $1997 .{ }^{74}$ In 2003, the MSRB noted "increasing signs" that its rules were deficient ${ }^{75}$ as reports circulated of the widespread use of lobbyists and political consultants. ${ }^{76}$ In 2005, the MSRB again amended its rules, prohibiting dealers, their affiliated entities, and their MFPs from soliciting others "to make or coordinate contributions to an official of an issuer from which the dealer is seeking municipal securities business."77 In 2006, the National Association of Securities Dealers, which enforces MSRB rules, announced that it would significantly increase penalties for violations of the rules regulating political contributions, again suggesting dissatisfaction with the existing regime. ${ }^{78}$

The history of the MSRB's efforts reflects a general problem: although regulations can redirect the flow of money from businesses to public officials with the power to assign valuable contracts, they cannot wholly impede it. For this reason, efforts to regulate contributions from class action lawyers to officials associated with public sector pension funds are also likely to enjoy limited success. Such regulations may also have unintended consequences stemming from Congress's failure to build selective incentives into the PSLRA. The growing involvement of public sector and union pension funds in securities class actions may reflect the impact of political contributions. If so, a successful effort to staunch these contributions may remove the incen-

73. Municipal Securities Rulemaking Board, MSRB Notice 2003-32 (Aug. 6, 2003), available at http:/www.msrb.org/MSRB1/archive/G-3738August2003.htm.

74. James Dao, Proposal to Restrict Campaign Contributions by Bond Lawyers Sets off a Debate, N.Y. TIMES, Aug. 2, 1997, at 22.

75. According to the MSRB, MFPs were making the following:

[P]ayments to political parties or non-dealer controlled PACs that find their way to issuer officials, significant political contributions by dealer affiliates (e.g., bank holding companies and affiliated derivative counterparty subsidiaries) to both issuer officials and political parties, contributions by associated persons of the dealer who are not MFPs and by the spouses and family members of MFPs to issuer officials, and the use of consultants who make or bundle political contributions. In addition to dealer and dealer-related giving, the [MSRB] [wa]s also concerned about media and other reports regarding significant giving by other market participants, including independent financial advisors, swap advisors, swap counterparties, investment contract providers and Id. public finance lawyers.

76. See, e.g., Justin Pope, With Bond Business Lobbying Thriving, Regulators Mull Ban, Postgazette.com, Mar. 29, 2004, available at http:/www.post-gazette.com/pg/pp/04089/291944.stm.

77. Schneider, supra note 70 , at 352.

78. Lynn Hume, Bigger Fines For MSRB Violations: New Penalties Slated to Rise as Much as $2000 \%$, Mar. 14, 2006, http:/www.financial-planning.com/pubs/fpi/20060314101.html. 
tives these funds have to volunteer, placing more securities class actions under the control of individual investors. This would undermine the PSLRA. Assuming the desirability of having sophisticated investors with large holdings at the helm, the best approach would not prohibit political contributions, but would render them unnecessary and irrelevant by creating other selective incentives. Part V discusses three such proposals.

\section{Building Selective Incentives into the PSLRA}

Although widely despised, political contributions have an important upside: they provide selective incentives for trustees to volunteer public sector and union funds as lead plaintiffs. If policymakers barred political contributions, these incentives would be lost. Because "public pension funds are generally viewed as the best potential monitors in securities class actions," such a bar would undermine the PSLRA. ${ }^{79}$

Political contributions are poorly suited to the task of motivating trustees to volunteer investment funds as lead plaintiffs. First, because these contributions flow to trustees rather than funds, they may cause the interests of trustees and funds to conflict. Partisan trustees want to maximize the flow of contributions to themselves or their supporters. Fund beneficiaries want to maximize the value of their pensions. Trustees may therefore litigate more or less than beneficiaries rationally want. ${ }^{80}$

Second, political contributions divert wealth from beneficiaries to other targets. The process of making and receiving political contributions can be conceptualized as an all-pay auction in which partisan trustees are selling and lawyers are bidding for the opportunity to earn fees in securities class actions. The value of this opportunity should flow to fund beneficiaries who lost investment dollars, not to partisan trustees who have other sources of compensation for time spent running public sector funds.

Third, judging from experience, political contributions do little to convince private institutional investors to enter the fray. Because pri-

79. Michael A. Perino, Markets and Monitors: The Impact of Competition and Experience on Attorneys' Fees in Securities Class Actions, at 15 (St. John's Univ. Legal Studies Research Paper Series, No. 06-0034, Jan. 2006), available at http://papers.ssrn.com/sol3/papers.cfm?abstract_id= 870577.

80. In theory, political contributions can encourage public sector and union pension funds to sue or discourage them from suing. In practice, contributions given to discourage funds from stepping forward have not been reported. 
vate investors may be the best lead plaintiffs in many cases, an incentive system that appeals to them would be desirable.

Fourth, political contributions taint class counsel appointments. Even if the taint is unwarranted in most cases-because partisan trustees hire outstanding attorneys and set their compensation at market rates $^{81}$-it is unfortunate and costly. The appearance of impropriety may undermine judges' confidence in lead plaintiffs' decisions and independence. It also creates disputes, as lawyers and investors competing for control of class actions use evidence of contributions to attack others' integrity.

It would be easy for policymakers to incorporate a better set of selective incentives into the PSLRA. The remainder of this Part considers several possibilities. The first proposal-awarding a lead plaintiff bonus-would require the smallest change to the PSLRA and would be most faithful to Congress's desire to place the lead plaintiff with the largest financial stake at the helm. The other proposals, which involve the use of auctions, are designed to put control in the hands of highly motivated investors to maximize class-wide recoveries, even more so than typical institutional investors. The investors who win the auctions may hold large blocks of securities prelitigation, but need not. These proposals thus depart from Congress's lead plaintiff model. As shown below, however, Congress's model has important defects.

\section{A. Award Lead Plaintiff Bonuses}

By prohibiting lead plaintiffs from receiving more than their pro rata shares of class-wide recoveries, the PSLRA entrenches the economic rationality of free-riding, ensuring that most institutional investors remain on the sidelines. This shortcoming can be repaired. For example, Congress could require judges to appoint as lead plaintiff the investor with the largest stake regardless of whether that investor applied for the post. ${ }^{82}$ The downside of this approach would be the risk of appointing an investor who did not want to be a lead plaintiff and would likely do a poor job, such as by settling immediately at a fire-

81. Coffee, Jr., When Smoke Gets In Your Eyes, supra note 64, at 246 ("[T]he attorneys who donate the most to the state controller of their choice are probably among the most able litigators who are most likely to maximize the state's recovery."). In Cendant, where political contributions led to considerable mudslinging, the lead plaintiffs negotiated a fee $\$ 76$ million below the lowest bid generated by the trial court's auction. 182 F.R.D. 144 (D.N.J. 1998). See generally Perino, supra note 22 (finding that, in percentage terms, fee awards are lower in class actions led by public pension funds).

82. How judges would assemble lists of investors by size is a matter we do not consider, given the hypothetical nature of this proposal. 
sale price to avoid litigation. One might consider an investor's expressed desire to become lead plaintiff a minimum condition for adequacy. Recognizing this, the PSLRA requires a judge to appoint the investor with the largest financial stake from the pool of investors who initiate litigation or nominate themselves after receiving notice.

Congress could also address free-riding by building selective incentives into the PSLRA. For example, Congress could authorize lead plaintiff bonuses. Although there is substantial latitude in formulating a bonus, its design should induce institutional investors to serve as lead plaintiffs. This would require larger bonuses for institutional investors than for individuals, as previously explained. ${ }^{83}$

A formula linking the bonus to the lead plaintiff's relative ownership interest would accomplish this result automatically. A lead plaintiff with $X$ shares of an issuer's stock might receive a fraction of the class-wide recovery based on $2 X$. For example, suppose an issuer had 900,000 shares outstanding and a lead plaintiff held 100,000 of these $(11 \%)$. The court would treat the lead plaintiff as holding 200,000 shares, bringing the total number of outstanding shares to one million. The lead plaintiff would then own $20 \%$ (200,000 divided by $1,000,000)$ of the recovery, and the bonus would be $9 \% .{ }^{84}$

In the preceding example, one could use a multiplier of three-or any other number greater than one-rather than two. If Congress tied the formula to the size of an investor's holdings, institutional investors would receive larger bonuses than individual investors, because they typically hold larger blocks of shares. ${ }^{85}$ Among institutions holding large blocks, the formula would also give the largest stake-

83. See supra Part IV.

84. The decision to use shares owned reflects the usual practice of allocating settlement funds on this basis. For simplicity, this example assumes that all investors bought shares at the start of the class period and held them until it ended. In other words, it assumes no trading. It also ignores other complications, such as options and multiple classes of stock. If these simplifications make the example seem unrealistic, one could tie the lead plaintiff bonuses to investors' losses, as the PSLRA does for the lead plaintiff position, rather than to the number of shares held. A lead plaintiff that lost $\$ 100$ million would be treated as having lost $\$ 200$ million.

85. The formula proposed in the text would work poorly if a single institutional investor held an enormous fraction of an issuer's stock-for example, $95 \%$. In these situations, the lead plaintiff's bonus would be small relative to its existing stake. Of course, in these situations the main investors' incentive to free-ride would also be minuscule. In any event, such situations are rare. Professors Weiss and Beckerman examined institutional investors' holdings in companies sued for securities fraud and found no instance in which a single investor held even a majority of the issuer's stock. Weiss \& Beckerman, supra note 12, at 2089-93. This is for good reason: a majority owner might monitor the firm well enough to prevent misdeeds or might play an active role in misdeeds, seeking to transfer wealth from minority shareholders to itself. Should policymakers think the need exists, they could deal with this remote contingency by capping the bonus so that the lead plaintiff's share would never expand above $30 \%$ of the recovery. A lead plaintiff with a share of $30 \%$ or more would receive no bonus. 
holder the largest reward, targeting the strongest selective incentive at the investor Congress had in its sights when crafting the PSLRA's lead plaintiff provision. A bonus tied to both the lead plaintiff's stake and the class-wide recovery would also enhance the lead plaintiff's incentive to maximize the recovery, making its recommendations regarding settlement more credible.

The proposed lead plaintiff bonus might be modified to accommodate a peculiar feature of the PSLRA, which identifies the "person or group of persons" with the largest financial stake as the presumptively most adequate plaintiff. ${ }^{86}$ Investor groups have won control of many cases, sometimes to the exclusion of institutions that also volunteered to serve as lead plaintiffs. ${ }^{87}$ This preference for investor groups is questionable. First, the groups suffer internal collective action problems. Every member wants other members to bear the cost of running the lawsuit. To overcome these problems, group members must expend resources that might otherwise be used to maximize the collective recovery. Second, there is no obvious reason to expect group members with small claims to perform better as lead plaintiffs than individual investors who control lawsuits on their own. Why should an investor with a small stake do a better job of selecting class counsel or bargaining over fees simply by virtue of belonging to a group? Third, to the extent that externally motivated investor groups exist, these groups must waste resources competing to become the largest group.

Still, the PSLRA expressly provides for lead plaintiff investor groups, and this may be advantageous. ${ }^{88}$ It would be easy to preserve this option while also offering the lead plaintiff bonus proposed in this Section. One could simply treat each member of a group as an individual lead plaintiff and award that person a bonus tied to the size of her stake. If the investors collectively held 100,000 shares, they would receive a fraction of the class-wide recovery based on ownership of 200,000 shares, as was true for a single lead plaintiff in the example above.

86. 15 U.S.C. \& 78u-4(a)(3)(B)(iii)(I) (2000) (emphasis added).

87. Cox \& Thomas, supra note 2 , at 1619.

88. Id. at 1639 (reporting that investor groups perform better than individuals in large cases, a finding that they attribute to the presence of individuals with sizeable stakes or institutions in those investor groups). 


\section{B. Auction Lead Plaintiff Bonuses ${ }^{89}$}

One could also create a selective incentive for the investor best able to represent a class to step forward by auctioning a recovery attached to the lead plaintiff spot. After notifying all class members that litigation has commenced and inviting them to apply for the lead plaintiff position, the court would sell a standardized share of the gross recovery-20\% - to the highest bidder. The court would hold the price paid by the winning investor for subsequent distribution to the class.

Competition in these auctions should be brisk. The possibility of obtaining a sizeable piece of a class-wide recovery at a bargain price should entice investors who would ordinarily free-ride. PricewaterhouseCoopers reported average settlement amounts of $\$ 71.1$ million for securities class actions resolved in 2005.90 Thirty settlements exceeded $\$ 20$ million. A $20 \%$ share of a successful case would be worth owning. ${ }^{91}$

Selling shares of this size would also put plaintiffs with large financial stakes in charge of every case. Under existing arrangements, small investors often serve as lead plaintiffs, partly because no investor holds a large fraction of an issuer's securities. ${ }^{92}$ Free-riding also contributes, because institutional investors with larger holdings simply fail to step forward. The proposed auction would thus convey two

89. Many sources address the possible use of auctions to regulate attorneys' fees in class actions. The consensus appears to be that the PSLRA, which assigns the lead plaintiff the power to "select and retain counsel to represent the class" subject only to judicial approval, prohibits the use of auctions for this purpose. See, e.g., Sherrie R. Savett, Plaintiffs' Vision of Securities Litigation: Trends/Strategies in 2005-2007, 1620 PLI/CoRP. 57, 87 (Sept.-Oct. 2007) (summarizing authorities and observing that "there has not been a single lead plaintiff/lead counsel determination based on bidding" since 2002). Other objections to class counsel auctions have also been raised, such as the plausible contention that the cheapest lawyer may not be the best lawyer for a class. For thorough discussions, see Fisch, supra note 67; Jill E. Fisch, Aggregation, Auctions, and Other Developments in the Selection of Lead Counsel Under the PSLRA, 64 LAw \& Contemp. Probs. 53 (Spring/Summer 2001); and Proceedings of the 2001 Third Circuit Task Force on the Selection of Lead Counsel, available at http://www.ca3.uscourts.gov/classcounsel/. Without endorsing these objections, it is important to note that many of them do not extend naturally to lead plaintiff auctions. The "cheapest lawyer" objection is one of these. The auction this Article proposes involves paying a cash bid in exchange for a fixed percentage of the recovery, which selects for the lawyer/plaintiff combination with the highest expected recovery.

90. PricewaterhouseCoopers LlP, 2005 Securities Litigation Study 18 (2006). PricewaterhouseCoopers reported median settlement amounts of $\$ 9.25$ million for securities class actions resolved in 2005 . Certain mega-settlements were excluded when the average and mean values were calculated.

91. The expected value would be less if one included unsuccessful cases.

92. Weiss \& Beckerman, supra note 12, at 2089-94 (reporting many instances in which the single largest claimant accounted for less than $10 \%$ of dollars paid out in a class action settlement and reporting that the mean share accounted for by the largest single claimant in twenty cases studied was $13.1 \%$ ). In many cases, then, auctioning even a $10 \%$ share of the recovery would strengthen the lead plaintiff's incentive substantially. 
advantages. In cases that currently lack investors with large holdings, it would create them. In cases where investors with large holdings exist but currently remain passive, it would encourage them to step forward by rewarding participation.

Competition should also redress two shortcomings of the first proposal, one of which is also associated with current practice. Under existing law, multiple investors seeking the role of lead plaintiff sometimes claim to have the largest financial stake in the defendant corporation. This competition produces litigation, ${ }^{93}$ which also occurs when claimants seek to better their odds of becoming lead plaintiffs by forming investor groups. ${ }^{94}$ Auctions would eliminate wasteful disputes over the size of investors' stakes by awarding control to the highest bidders.

An auction would also be superior to the lead plaintiff incentive bonus, because it would set the net cost of the bonus at the lowest level sufficient to attract a savvy and highly incentivized litigation manager. The proposal set out in the preceding Section tied the size of the bonus to the lead plaintiff's investment, an arrangement calculated to give bigger investors stronger incentives. However, in any given case, this rough arrangement may generate a bonus that is too large or too small. In one limiting case, it might confer an additional payment on an investor who would happily take the lead without one. Here, the class would bear a needless cost. In another limiting case, the bonus might be too small to convince the best litigation manager to sign on. Here, a class would likely benefit by paying more.

By auctioning the lead plaintiff bonus, judges would create markets in which investors reveal their valuations. Investors would assemble litigation teams to evaluate cases and establish bid amounts. The high bidder for the bonus share would then be the investor capable of maximizing the share's expected net value. This bidder would also likely be the class member best able to maximize the net expected value of the entire case.

By selling a $20 \%$ share to the highest bidder, a judge would also reduce the class's net cost of the bonus to the lowest level sufficient to

93. See, e.g., In re Enron Corp. Sec. Litig., 206 F.R.D. 427 (S.D. Tex. 2002) (discussing the size of competing plaintiffs' claims and the law governing this determination); Beth Bar, Lerach's Bid for Lead Counsel Status Rejected in Comverse Class Action, N.Y. L.J., Mar. 6, 2007, at 1 (reporting that a district court judge reversed a magistrate judge's decision to appoint the Plumbers and Pipefitters National Pension Fund lead plaintiff on finding that another investor, "the Menorah Group, purchased the greatest number of net shares of [the defendant's] stock, [and] expended the greatest number of net funds and suffered the greatest loss." (internal quotation marks omitted)).

94. Cox \& Thomas, supra note 2, at 1619. 
attract the best lead plaintiff. The class would recover not just $80 \%$ of the settlement (the amount remaining after paying the lead plaintiff), but $80 \%$ plus the amount paid by the lead plaintiff for the right to represent the class. The high bidder's payment would help the class.

Bids would also vary with the merits of a case. The stronger the case, the smaller the premium needed to convince a potential lead plaintiff to step forward. Because the lead plaintiff would trade cash up front for a much larger share of the recovery, the lead plaintiff's incentive to maximize the recovery would be strong, even in easy cases that require small premiums. For example, suppose the high bidder paid $\$ 15$ million for a $20 \%$ lead plaintiff share expected to be worth $\$ 20$ million out of a $\$ 100$ million recovery. The premium would therefore only be $\$ 5$ million ( $\$ 20$ million - $\$ 15$ million $=\$ 5$ million) in a case with an expected gross recovery of $\$ 100$ million and a $\$ 95$ million recovery for the class after subtracting the lead plaintiff bonus ( $\$ 100$ million $-\$ 20$ million $+\$ 15$ million $=\$ 95$ million $)$. The proposed auction would cost the class something, but would also strengthen the lead plaintiff's incentive considerably. The improved incentive would further reduce the cost - or perhaps even eliminate it - by improving litigation governance and generating higher returns.

Institutional investors with large holdings would enjoy advantages in these competitions, but would not be guaranteed to win. Their position would still be privileged. First, as repeat players in lead plaintiff auctions, they could amortize the fixed costs of case evaluations across a series of competitions. Second, they could afford to be risk neutral. A $\$ 500,000$ loss in a single lawsuit might devastate a small investor. The same loss would merely be unpleasant for the managers of a $\$ 100$ million investment fund. Third, institutional investors' larger prelitigation holdings would reduce agency costs and give them stronger incentives to bid. Compare an institution holding $10 \%$ of an issuer's securities prelitigation to an individual investor holding $0.5 \%$. After winning the $20 \%$ stake to be sold at auction (ignoring attorneys' fees), the institution would own $28 \%$ of the recovery. The individual investor would barely own more than $20 \%$. The institutional investor would therefore internalize about $40 \%$ more- .28 versus .20 -of the return on each dollar expended in litigation. Thus, the institution's incentive to invest in the case would exceed the individual's, making the case worth more in the institution's hands and enabling it to outbid the individual. Having a larger share, the institutional investor would also be more concerned about attorneys' fees and would presumably invest more effort in setting them correctly. The large share creates a responsibility for the manager and provides an indirect in- 
centive to manage the size of the fee. This indirect incentive would likely mitigate the effect of lobbyists' political contributions and other emoluments.

Institutions with large holdings would not always prevail in auctions, however. They would predictably lose to investors with smaller stakes who were superior litigation managers. Given the number of cases filed per year-between one hundred and two hundred-and, therefore, the number of auctions, one might expect litigation specialists to emerge. These specialists, who might be small- or mediumsized investors closely aligned with excellent class action attorneys, could outbid institutional investors in many cases.

The possibility that an investor with a smaller stake could outbid one with a larger stake signals yet another flaw in the PSLRA, not a defect in the auction proposal. The PSLRA uses an investor's financial stake as a proxy for ability to maximize a class action recovery. The proxy may be flawed. ${ }^{95}$ Interest conflicts may undermine large investors' enthusiasm for litigation. Institutions with large stakes may also be inferior litigators. Their profession is investing, not litigating. Few institutions lead more than one or two cases per year. ${ }^{96}$ Assuming a properly designed auction, a plaintiff's willingness to pay for the lead position would better indicate its ability to maximize the expected recovery than the size of its investment.

An example may be helpful here. Suppose Investor A, which holds $5 \%$ of an issuer's securities, thinks that, if he gains control of a lawsuit, a $20 \%$ share of the expected recovery is worth $\$ 30$ million. Now suppose Investor $\mathrm{B}$, a litigation specialist, who holds only $1 \%$ of the securities, thinks the same share would be worth $\$ 60$ million if he were in charge. Ceteris paribus, Investor B will bid more for the lead plain-

95. For example, some contend that public sector funds make the best lead plaintiffs because they have large investment portfolios and fewer conflicts than private funds. See Perino, supra note 22. This is a contestable proposition. Public sector trustees may or may not be sophisticated litigation managers. Moreover, it is not self evident that financial stake should be determinative when, as sometimes occurs, multiple public sector funds volunteer to be the lead plaintiff. A public fund with a $5 \%$ stake could be a better litigation manager than one with a $5.5 \%$ stake. A multi-attribute auction that includes both stake and cash payment could standardize the weight that courts apply to each. This Article strongly recommends that courts determine such weights before an auction rather than using an auction as the opening round of a hearing.

96. Reacting against "professional plaintiffs," Congress limited the number of times an investor can hold the lead plaintiff position. 15 U.S.C. $\$ \S 77 \mathrm{z}-1(\mathrm{a})(3)(\mathrm{B})(\mathrm{vi}), 78 \mathrm{u}-4(\mathrm{a})(3)(\mathrm{B})(\mathrm{vi})$ (2000) (" $[\mathrm{A}]$ person may be a lead plaintiff, or an officer, director, or fiduciary of a lead plaintiff, in no more than 5 securities class actions brought as plaintiff class actions pursuant to the Federal Rules of Civil Procedure during any 3-year period."). This prohibition may have made sense when lead plaintiffs were figureheads. It is unwarranted in a world where lead plaintiffs are effective litigants. 
tiff position than Investor A. Other class members will benefit as a result, because the better lead plaintiff will be at the helm. ${ }^{97}$

The PSLRA limits the frequency with which the same person may appear as a lead plaintiff. ${ }^{98}$ In theory, this restriction could prevent specialists from developing. In practice, it may be toothless. ${ }^{99}$ It expressly allows judges to make exceptions "consistent with the purposes of [the lead plaintiff provision]."100 It is also written in a way that may allow litigation specialists to use strategic behavior to nullify it, perhaps by employing investors who have not previously served as lead plaintiffs.

Even so, the merits of the restriction should be considered. Why limit the frequency with which investors can serve as lead plaintiffs? Practices prevailing before the adoption of the PSLRA were influential: "Once, some securities class lawyers used professional plaintiffs who held very diversified portfolios with a few shares in most companies."101 These professional plaintiffs were not litigation specialists; they were hand-picked clients, who were valuable because of their availability and their willingness to serve without asking questions. Because they possessed small stakes, they had little reason to actively manage the lawsuits in which they appeared.

The auctions proposed in this Section would not facilitate the return of the professional plaintiffs, whose activities Congress sought to regulate via the PSLRA. They would favor litigation specialists and would incentivize those specialists to maximize shareholders' recoveries. The restriction on professional plaintiffs should therefore not apply to auction winners. It may even have outlived its usefulness already. The large public sector and union funds that currently serve as lead plaintiffs are gaining experience as litigation managers and building track records in large cases. "[A] demonstrated record as a diligent monitor of the present suit, when coupled with a good track record of being such a monitor in other cases, should ... persuade the court

97. If other things are not equal, good litigation specialists will be rewarded and poor litigation specialists will be punished, causing them to exit the industry quickly. Poor litigation specialists will pay more in auction bids than they receive in fees or receive returns on their bids that are unprofitable. Neither result is viable over the long-haul.

98. See supra note 96.

99. But cf. In re Enron Corp. Sec. Litig., 206 F.R.D. 427 (S.D. Tex. 2002) (rejecting the Florida State Board of Administration's bid for lead plaintiff position partly because of prior involvements in class actions exceeding the limit set in the professional plaintiff provision).

100. Id. at 443 .

101. Coffee, Jr., supra note 28 , at 7 . 
that the petitioning institution has only the positive characteristics associated with being a professional plaintiff." 102

As noted above, the PSLRA allows groups of investors to serve as lead plaintiffs. If the auction approach proposed in this Section were in place, the need for this provision would disappear. Every auction would produce a single winner, whose incentives would be superior to those of most lead plaintiffs selected today. The winner could be a consortium of stockholders, but whether it is a group or individual would be inconsequential. A consortium could handle its internal operations contractually and participate in an auction as a single person or entity. ${ }^{103}$

Auctions would favor investor groups only when groups were in the best position to maximize expected recoveries. In theory, a group of investors could solve internal difficulties and become a superior litigation manager. That group would be able to win auctions by outbidding its competitors. It would pay the most for the proposed lead plaintiff bonus, because it could generate the highest expected recovery. This is precisely when a group should gain control of a class.

Like the simple bonus proposed above, an auction would also incentivize all types of investors, including private sector funds. By choosing to stay on the sidelines, managers would forfeit the opportunity to earn profits for private funds. In effect, auctions would reverse the current state of affairs, in which managers' fiduciary duties encourage them to free-ride, by creating opportunities for their funds to make significant returns. For example, suppose an auction presents an opportunity to bid on a $20 \%$ share in a lawsuit with a $\$ 100$ million expected recovery. Suppose further that no investors bid, so that a $\$ 1$ bid would win. By failing to bid $\$ 1$, a manager would deprive a group of fund beneficiaries of an expected $\$ 30$ million, surely an act of malfeasance. ${ }^{104}$ To guard against breach of duty lawsuits by disgruntled beneficiaries, fund managers would submit bids at defensible levels. This would encourage competition. ${ }^{105}$

102. Cox \& Thomas, supra note 2 , at 1638 .

103. A similar problem arises in class actions and consolidations, where attorneys working in groups often use contracts to assign burdens and benefits. See Charles Silver, Comparing Class Actions and Consolidations, 10 Rev. Litig. 495 (1991).

104. This example ignores other costs a private fund may incur while serving as a lead plaintiff.

105. Auctions would reduce, but perhaps not eliminate, the incentive large investors sometimes have to opt out of class actions and sue on their own. The incentive would diminish because auctions would be likely to put high-quality litigation managers in charge of class suits, making separate litigation less attractive. The incentive would not disappear, however, because auctions would not eliminate the problem of claim dilution that sometimes occurs when institutions' claims are mixed with those of individual investors. 
Although a $20 \%$ bonus would help accomplish Congress's objective of moving from lawyer-driven to plaintiff-driven litigation, it might not succeed entirely. Class counsel's interests could still exceed a lead plaintiff's stake. Historically, fee and cost awards have often exceeded $20 \%$. Fees in this range have also been awarded in cases commenced after the effective date of the PSLRA. If the person with the largest stake calls the shots, lawyers may continue to run many class actions.

On the other hand, lead plaintiffs have the power to keep domineering lawyers in check. A lead plaintiff can fire its law firm or use the prospect of future business to elicit cooperation. At the end of a case, a lead plaintiff can also ask a judge to reduce class counsel's fee. But would a lead plaintiff be sufficiently independent and headstrong to apply these punishments? The auction proposed in this Section would be more likely to put such plaintiffs in charge of class actions for two reasons. First, all lead plaintiffs would have more "skin in the game"-after winning the auction, a lead plaintiff holding $5 \%$ of a company's securities would own more than $20 \%$ of the class-wide recovery. Lead plaintiffs rarely have interests this sizeable today. ${ }^{106}$ By increasing the lead plaintiff's stake, auctions would make independent judgment more likely. Second, the sunk costs associated with the bidding process would even the scales psychologically, if not economically. Having paid, for example, $\$ 1$ million for a $20 \%$ share, a lead plaintiff would likely consider itself an equal partner with class counsel. ${ }^{107}$ The equalizing effect of sunk costs may be especially important in cases led by public sector investment funds, whose trustees received political contributions. Having spent $\$ 1$ million in fund assets ${ }^{108}$ to obtain the lead role, a trustee would face special pressure to show that political contributions did not influence her judgment when hiring counsel.

106. Cox \& Thomas, supra note 2, at 1620 (reporting that in only two of the public pension fund cases in their data set did the lead plaintiff hold over $25 \%$ of the claims made in the case).

107. Counsel's sunk costs may vary enormously in size. Especially after the PSLRA imposed a heightened pleading standard on securities fraud cases, lawyers often expended significant resources before formal discovery occurred to acquire information about wrongdoing. In those cases where significant costs are incurred by counsel, a lead-plaintiff auction would still empower lead plaintiffs.

108. An interesting question is whether to allow persons bidding for the lead plaintiff role to use funds supplied by others, such as lawyers seeking to become class counsel. Allowing this would completely vacate the interest in having non-lawyer plaintiffs lead the litigation. Nevertheless, the team would be highly motivated with a well-established property right in the outcome. If the lack of independence in setting fees and establishing settlement currency can be cabined, lawyer-funded litigation may be more beneficial to the class. 
By substantially increasing the lead plaintiff's share of recovery, this proposal offers new opportunities to efficiently set attorneys' fees. For example, Congress could allow the winning bidder to set the fee percentage, while also requiring the winner to pay half of the final fee award. To see how this might work, suppose that the lead plaintiff holds a $20 \%$ share of the recovery and promises class counsel a $25 \%$ fee. Now suppose the lawsuit settles for $\$ 100$ million. Class counsel would receive $\$ 25$ million in fees, with the lead plaintiff and the class each contributing $\$ 12.5$ million. The lead plaintiff would net $\$ 7.5$ million ( $\$ 20$ million $-\$ 12.5$ million $=\$ 7.5$ million $)$. Saddling the lead plaintiff with a disproportionate fee obligation would create an incentive to avoid overpaying.

This incentive would not be perfect. Only concentrating $100 \%$ of the recovery interest in the hands of a single owner could encourage optimal fee setting. Under the hypothesized arrangement, the lead plaintiff would pay $50 \%$ of the marginal cost of litigation, but only get $25 \%$ of the marginal benefit. Presumably, this incentive mismatch would cause the lead plaintiff to underinvest. Even so, the proposed arrangement would be an improvement. First, the lead plaintiff's stake would be large enough to make it difficult for attorneys to use political contributions or other means to inflate their fees. Second, charging lead plaintiffs disproportionately for class counsel fees would discourage the lead plaintiff from favoring class counsel over the class. Third, the proposed mechanism would reduce the pressure on judges to cut fee requests by incentivizing lead plaintiffs to do that job up front.

The last point is worth expanding. Fee awards in class actions are highly controversial. ${ }^{109}$ Few judges want to be known for making plaintiffs' attorneys millionaires. Judges also bear a duty to protect absent class members from exploitation. Consequently, judges often cut lawyers' fee requests. Yet, when enormous fee awards are needed to incentivize attorneys to maximize class members' recoveries, enormous fees should be paid. Under existing arrangements, the urge to reduce fees below efficient levels probably wins out more often than it should. Judges usually set fees ex post, after they know the size of the proposed settlement and have eliminated the litigation risks. Judges also lack the data and economic models needed to optimally set fees.

109. The literature on fee awards is far too vast to summarize here. Many of the points made in that literature can be found in Task Force on Contingent Fees, Tort Trial \& Ins. Practice Sec. of the Am. Bar Ass'n, Report on Contingent Fees in Class Action Litigation, 25 Rev. Liric. 459 (2006). See also Charles M. Silver, Dissent from Recommendation to Set Fees Ex Post, 25 Rev. LITIG. 497 (2006). 
Finally, the cost of setting fees too low is invisible. The recovery, had the lawyers been optimally incentivized, is unknown. Consequently, no one can calculate the difference between the actual settlement and the optimal recovery.

The existing fee setting process also requires judges to step out of their customary roles. As absent plaintiffs' guardians, judges are supposed to select the best named plaintiffs and lawyers for a class and motivate the class's agents to maximize the net recovery. These are odd tasks for judges to perform. The best lead plaintiff, lawyer, and fee arrangement for the absent class members are the worst lead plaintiff, lawyer, and fee arrangement for the defendant. In effect, judges are supposed to help build litigation teams that enable class members to extract payments from defendants and design those teams so as to make the payments as large as possible. To describe this role is to wonder how neutral judges can play it.

\section{Auction Shares of Gross Recovery from Which Class Counsel Must Be Paid}

Finally, the authors' preferred approach is as follows: a simple auction in which persons-including but not limited to institutional investors-would bid for ownership of $30 \%$ of any funds recovered by judgment or settlement in a particular case. ${ }^{110}$ This approach would eliminate fee and cost awards from common funds, judicial control of fees and costs, and bonus payments for lead plaintiffs. Lead plaintiffs would set fees and pay them from their own recoveries. Class members would share the remaining $70 \%$ of the recovery, plus the amount paid by the winning bidder.

This approach resembles the lead plaintiff bonus auction described in the preceding Section. The highest bidder wins the right to a disproportionate share of the recovery after paying the amount bid into the court for subsequent distribution to the rest of the class. The high bidder is then appointed lead plaintiff and retains class counsel, offering as fees whatever terms she desires, including a flat fee, an hourly rate, or a contingent fraction of the high bidder's recovery. In practical effect, the lead plaintiff would spend her own money when hiring class counsel, eliminating the danger of overspending and the need for judicial review of the fee. The lead plaintiff's share is larger- $30 \%$

110. In theory, bidding could be opened to all comers, including noninvestors and even the defendant. In practice, one may wish to limit bidding to investors to avoid controversies over standing. Allowing a defendant to bid would raise different problems, including asymmetric access to inside information about alleged misconduct. 
versus $20 \%$-reflecting the lead plaintiff's increased responsibility for the fee.

The lead plaintiff's $30 \%$ share would be paid off the top of the class's recovery. The remaining $70 \%$ of the recovery would be divided among class members, including the lead plaintiff, in proportion to their ownership of the issuer's shares. For example, if the winning bidder held $10 \%$ of the issuer's stock and the class action settled for $\$ 100$ million, the lead plaintiff would receive $\$ 30$ million for the auctioned share plus $\$ 7$ million for the $10 \%$ interest. ${ }^{111}$ Netting out the lead plaintiff's payment, the distribution per share to other class members would be the same as it is when, under current arrangements, class counsel receives a $30 \%$ fee and cost award. The cost of maximizing the recovery, including the lead plaintiff's bonus, is thus amortized across the entire class.

The lead plaintiff's share of the class-wide recovery should be $30 \%$ for two reasons. First, $30 \%$ is approximately the historical average for fee and cost awards to lead plaintiffs and class counsel in securities class actions. Therefore, using it assigns the lead plaintiff roughly the same fraction of class-wide recoveries that has traditionally been used to defray litigation costs. Second, given economies of scale in litigation services and spillover effects, it stands to reason that a lead plaintiff's efforts to maximize the $30 \%$ share would go a long way toward maximizing the recovery for the entire class.

This auction approach has several advantages over existing arrangements. First, as explained above, it eliminates the need for judges to set fees or review the reasonableness of fees to which lead plaintiffs agree. The PSLRA requires these reviews, but it gives judges no standards to apply. In particular, the PSLRA provides no guidance concerning the circumstances in which judges should second-guess fees promised by lead plaintiffs. The PSLRA thus creates uncertainty regarding the enforceability of lead plaintiffs' promises, which can only weaken class counsel's incentives.

Presumably, lawyers would win some auctions for control of securities class actions-and they might win many. Class action lawyers are litigation specialists. As such, they are better suited than many to evaluate the profitability of class actions. They could also provide inhouse legal services, eliminating the principal-agent problems facing nonlawyer lead plaintiffs. Finally, lawyers have recently developed

111. ( $\$ 100$ million - $\$ 30$ million) $* 10 \%=\$ 7$ million. This equation ignores the amount the lead plaintiff bid to win the auction and any costs the lead plaintiff incurred while managing the case, such as lost managerial time and time expended by lower level personnel responding to discovery requests. The lead plaintiff's net recovery would be less than $\$ 37$ million. 
significant abilities to raise litigation capital. Law firms that concentrate on serving as lead plaintiffs might even arise, just as specialized class action law firms exist today.

The identity of the winning bidder notwithstanding, the incentives to invest in litigation created by the auction would not be perfect. Under the proposed arrangement, the lead plaintiff would receive at most $30 \%$ of the marginal benefit from litigation outlays. The remaining $70 \%$ would go to the class. Depending on the fee arrangement with class counsel, the lead plaintiff's share of the return could actually be $0 \%$. This would be true if the fee agreement entitled class counsel to $100 \%$ of the lead plaintiff's share of any recovery within a specified range. ${ }^{112}$ Presumably, this incentive mismatch would cause the lead plaintiff to underinvest relative to the optimal level for the class.

Perfection is, however, an impossible goal. The underinvestment problem described in the preceding paragraph afflicts all contingent fee lawsuits-in all such cases, the plaintiff receives only a fraction of the return on attorney effort and other investments in litigation. In class actions today, for example, the named or lead plaintiff typically has a minute interest in marginal dollars recovered. Class counsel's interest is much larger, but is weakened by uncertainty about the size of the fee award and by the tendency of judges to cut fee percentages as recoveries rise. ${ }^{113}$ Given the deficiencies of current arrangements, the question is not whether this proposal is perfect, but whether it would likely be an improvement.

Several reasons support an affirmative answer. First and foremost, lead plaintiffs and their lawyers would be free to address the incentive mismatch contractually, taking advantage of their ingenuity and the connection between the size of the bonus and the recovery for the class. The mismatch is both well known and predictable. Innovative fee arrangements can mitigate its effects. For example, increasing marginal fee percentages could offset falling returns on litigation investments or declining economies of scale. Increasing percentages would encourage class counsel to keep working despite falling returns or rising costs. Declining marginal fee percentages could be used in other situations, such as when expected returns depend less on litigation investments and more on matters beyond class counsel's control.

112. For example, a possible fee arrangement would entitle the lead plaintiff to the entire bonus on the first $\$ 10$ million recovered and class counsel to the entire bonus on the second $\$ 10$ million recovered. The lead plaintiff's return from the second $\$ 10$ million would be zero.

113. See Theodore Eisenberg \& Geoffrey P. Miller, Attorneys Fees in Class Action Settlements: An Empirical Study, 1 J. Empirical Legal Stud. 27 (2004). 
Although no single fee arrangement is likely to be best in all situations, the auctions proposed in this Section would motivate bidders to find the arrangement best suited to their case.

Currently, the ingenuity lead plaintiffs and class counsel might use to benefit all class members is lost. Lead plaintiffs gain too little from optimal fee setting to invest significant resources. Lead plaintiffs also share control of fees with judges who have neither an economic interest in selecting optimal fee arrangements nor the data or savvy needed to do so. In this context, one can therefore reasonably expect private arrangements negotiated by interested and sophisticated people to outperform regulations imposed from above.

Second, because lead plaintiffs would pay fees from their own pockets, the auctions proposed in this Section would make it extremely difficult for attorneys to use political contributions, lobbyists, or other means to inflate their fees. Charging lead plaintiffs for class counsel fees would completely externalize the problem of the lead plaintiff favoring class counsel over the class. The proposed mechanism would eliminate pressure on judges to cut fee requests, because all shareholder classes would receive the same fixed percentage. Only the payment to the class from the winning bidder would vary across cases, and the auction process would maximize it without judicial interference.

Allowing lawyers to win lead plaintiff auctions might be troubling. Opposition to lawyer-driven litigation in Congress led to the PSLRA, yet the proposed auctions would sometimes put lawyers squarely in charge of securities class actions. Many judges also have a policy against lawyers serving as named plaintiffs and class counsel in the same case. Finally, state bar rules prohibit lawyers from acquiring proprietary interests in their clients' causes of action.

These considerations do not outweigh the benefits of this proposal. All relate, in one way or another, to adequacy of representation. Congress's concerns about lawyer-driven litigation reflected an underlying belief that lawyers used securities fraud class actions to advance their own interests at shareholders' expense. The auction proposal set out in this Section ameliorates this concern by giving winning biddershere, lawyers-strong incentives to maximize class-wide recoveries and by relieving absent class members of concerns about fees. The doctrinal prohibition also reflects the concern that interest conflicts make it improper for lawyers to serve as named plaintiffs and class 
counsel concurrently. ${ }^{114}$ Under the auction proposal set out in this Section, however, combining the roles of lead plaintiff and class counsel limits the principal-agent problems that arise when these roles are separated. Finally, state bar rules regulating case financing were not written with class actions in mind. Courts should ignore these rules when they conflict with the proper operation of class actions, as they often do. 115

It is worth exploring the incentives of winning lawyer-bidders a bit further. Today, attorneys' fees in the largest class actions may be as low as $5 \%$ of the recovery and as high as $20 \%$ or more. ${ }^{116}$ This flat rate approach may both overcompensate class counsel for recovering "easy" dollars-dollars a defendant is willing to pay because of the merits of a case-and undercompensate class counsel for recovering "hard" dollars-dollars a defendant is willing to pay only because of class counsel's superior effort. The auctions proposed in this Section would address the overcompensation problem in the bidding process. Expected overcompensation would be returned to the class via the winning bidder's payment. Expected undercompensation would be reduced by giving the winning lawyer-bidder a constant $30 \%$ interest in all marginal dollars recovered. A winning lawyer-bidder would always be motivated to work hard for hard dollars, unlike today's class counsel, whose economic stake in hard dollars may be small.

Auctions would also improve settlement bargaining. Currently, bargaining often occurs in stages. Class counsel first negotiates a recovery for the class then negotiates a separate fund to cover attorneys' fees. ${ }^{117}$ In the first stage, class counsel's interests are conflicted. Having some idea of the total amount the defendant is willing to pay, class counsel's economic interest lies in directing the largest possible fraction of that amount to the fee fund. The chief impediment to class

114. On lawyers serving as named plaintiffs and class counsel simultaneously, see ALBA Conte \& Herbert B. Newberg, Newberg on Class Actions $\$ 3: 40$ (4th ed. 2002). "Most courts have held that such a dual role is "inherently fraught with potential conflicts of interest.'” Id. (quoting Graybeal v. Am. Sav. \& Loan Ass'n, 59 F.R.D. 7, 13 (D.D.C. 1973)).

115. See Charles Silver, Due Process and the Lodestar Method: You Can't Get There From Here, 74 TUL. L. Rev. 1809 (2000) (arguing that the due process imperative to minimize conflicts between class counsel and absent class members requires judges to refrain from using the lodestar method, even when state bar rules hold to the contrary).

116. Eisenberg \& Miller, supra note 113 , at 75.

117. Inexplicably, the Manual for Complex Litigation recommends this approach. MANUAL For Complex Litigation, Fourth § 21.7 (Stanley Marcus et al. eds., 2004). "[T]he simultaneous negotiation of class relief and attorney fees creates a potential conflict." Id. (citing In re Prudential Ins. Co. Am. Sales Practice Litig. Agent Actions, 148 F.3d 283, 334-35 (3d Cir. 1998)). "Separate negotiation of the class settlement before an agreement on fees is generally preferable." Id. 
counsel's avarice is the fear that a judge will cut the fee or reject the settlement if the ratio between the class fund and the fee fund is too low. When negotiating, class counsel therefore targets the lowest recovery-to-fee ratio a trial judge will approve, rather than solely seeking to help the class. In an effort to dispose of cases, judges may even facilitate this corrupted bargaining process by signaling their views on fees in advance. ${ }^{118}$

The negotiations just described contrast sharply with settlement bargaining in standard contingent fee representations. When representing a client injured by an automobile accident or a medical mistake, the plaintiff's attorney simply bargains for the largest possible recovery. The fee falls out automatically once this sum is obtained, because the parties set it prior to negotiations in the client's retainer agreement. The negotiations are still suboptimal, as they must be when a bargaining agent receives less than $100 \%$ of the marginal dollars, but the incentives are aligned and only differ in magnitude.

With the auction proposal in place, settlement bargaining in securities class actions would follow the conventional contingent fee model. The parties' interests would be aligned, because the winning lawyerbidder's share of the recovery would be fixed at $30 \%$ in advance. Fees would never be negotiated separately. As in conventional representations, settlement negotiations would focus solely on the defendant's total payment.

Auctions would create a desirable feedback loop. By winning cases, lawyers would obtain more money with which to bid on future cases and develop reputations for success that would reduce their borrowing costs. Unsuccessful lawyers would be forced out of the competition. Law firms would enter the field, leave it, and expand and contract based on their confidence, as well as their willingness and ability to pay. This healthy market dynamic would make the securities plaintiffs' bar more effective and more profitable over time-though perhaps less profitable than firms are today in the absence of this form of competition. This would correct the current market failure, in which the market does not fully determine which lawyer represents a class, what class counsel is paid, or which law firms succeed.

\section{Conclusion}

The PSLRA has failed to make private institutional investors active participants in securities fraud class actions. Pension funds for public

118. While judges increase certainty by telling attorneys the maximums they will award, their maximums may be too low to motivate hard dollar recovery or too high for easy dollar recovery. 
sector and union employees have often served as lead plaintiffs, and their participation rates are increasing. Yet individual investors still control many class actions. The motivations of public sector and union pension funds may also be suspect. Political contributions from, and lobbying efforts by, plaintiffs' law firms have raised questions about these funds' independence and prompted others to challenge their efforts to become lead plaintiffs.

These problems stem from the structure of the PSLRA, which is deficient in many respects. Most importantly, the PSLRA lacks the selective incentives needed to convince institutional investors of all types that securities lawsuits are worth their time. The bonuses that motivate individual investors to serve as lead plaintiffs mean nothing to institutional investors. This explains the passivity of private institutions and the importance of political contributions and ideology in the realm of public and union funds.

Regulations on political contributions would be, at best, a half-step in the right direction and, at worst, a sizeable step backwards. If successful, these measures would remove the cloud that presently hangs over public sector and union funds. But these measures would also remove a reason these institutions have to step forward. By eliminating the selective incentives political contributions provide, they might reduce the rate at which public sector and union funds volunteer as lead plaintiffs, restoring the status quo that existed prior to the PSLRA, in which individual investors led the vast majority of cases.

The PSLRA and restrictions on political contributions have a common failing: they will only succeed if stockholders are angels. If investors were inherently ethical, selfless, and good fiduciaries, they would make excellent lead plaintiffs and would volunteer for the role regardless of the incentives. But stockholders, especially institutions, are not angels. They are hard-nosed participants in unforgiving markets who must seek to minimize costs and maximize profits. Given this, it is unreasonable to expect a regulatory system that provides weak participation incentives to lure institutional investors into securities class actions in large numbers.

Rather than indulge the fantasy that investors are angels, this Article assumes that they are selfish, profit-motivated, and not above ethical lapses. A critic of rational actor models might say that this assumes investors are devils who pursue the greater good only when they can help themselves by doing so. These assumptions about investors' motivations lead to a simple conclusion: institutional investors will become lead plaintiffs in larger numbers when selective incentives 
make it economically advantageous for them to volunteer. This Article's proposals reflect that belief.

These proposals have many virtues, and the proposal to auction a lead plaintiff share that includes the payment of fees is the most desirable. Each proposal requires a minimum of judicial involvement. The simple lead plaintiff bonus approach requires almost none. Each proposal is likely to give the investor with the largest stake in the outcome both a significant incentive and a significant advantage. The auction proposals would favor smaller investors only when they are likely to litigate more successfully than larger ones. These proposals would also give lead plaintiffs strong incentives to negotiate optimal fee deals and protect absent class members from overpayment by charging disproportionate shares of fees to lead plaintiffs and subjecting lead plaintiff bonuses to competitive market tests. Finally, fixing the size of the lead plaintiff's share and class counsel's fee in advance would create stronger incentives to invest in litigation and eliminate the rivalry between the class and its representatives that exists when the fees are discretionary. By giving control to the lead plaintiff, whose willingness to pay demonstrates its potential to obtain the highest recovery, auctions would fulfill the promise of the PSLRA and better serve investors. 
